Jurnal Al-Adalah: Jurnal Hukum dan Politik Islam

Vol. 4, No. 1, Januari 2019: 52-81

P-ISSN: 2406-8802

E-mail: aladalah@iain-bone.ac.id

http://jurnal.iain-bone.ac.id/index.php/aladalah

\title{
Persetujuan Majelis Kehormatan Notaris Wilayah Dalam Pengambilan Minuta Akta Dalam Proses Peradilan
}

\author{
Andi Nurfajri Riandini Arief, Syukri Akub, Syamsuddin Muchtar \\ Fakultas Hukum Universitas Hasanuddin \\ E-mail: riandiniarief@gmail.com
}

\begin{abstract}
:
This study aims to examine the importance of the approval of the Regional Notary Honorary Council in taking photocopies of the minuta notary deed for examination in criminal cases carried out by notaries and inspection mechanisms by the Regional Notary Honorary Council in approving alleged criminal acts committed by Notaries. This research is empirical juridical research. The results of the study show that the Honorary Board of Notaries in the South Sulawesi Province still get obstacles in carrying out their duties and functions, especially in giving decisions both in approval and rejection of requests from law enforcement officials. Based on the results of the study the authors inventory the obstacles that come from notaries and law enforcement officials as well as in terms of legal rules. The suggestion in the future is the need for continuous guidance to notaries and law enforcement officials so that both parties can understand their respective positions in carrying out the profession as well as understanding the duties and functions of the Regional Notary Honorary Council.
\end{abstract}

\section{Key Word : Approval; Honorary Council; Notary; Minuta Notary Deed Abstrak:}

Penelitian ini bertujuan untuk menelaah pentingnya persetujuan Majelis Kehormatan Notaris Wilayah dalam pengambilan fotokopi minuta akta untuk kepentingan pemeriksaan dalam perkara pidana yang dilakukan oleh notaris serta mekanisme pemeriksaan oleh Majelis Kehormatan Notaris Wilayah dalam memberikan persetujuan terhadap dugaan tindak pidana yang dilakukan oleh Notaris. Penelitian ini adalah penelitian yuridis empiris. Hasil penelitian menunjukkan bahwa Majelis Kehormatan Notaris Wilayah Provinsi Sulawesi Selatan masih mendapatkan hambatan dalam melaksanakan tugas dan fungsinya khususnya dalam memberikan keputusan baik persetujuan maupun penolakan terhadap permohonan dari aparat penegak hukum. Berdasarkan hasil penelitian penulis menginventarisir hambatan yang berasal dari para notaris dan aparat penegak hukum serta dari segi aturan hukum. Adapun saran kedepannya adalah diperlukannya pembinaan secara terus menerus kepada para notaris dan aparat penegak hukum agar kedua pihak dapat memahami kedudukan masing-masing dalam melaksanakan profesi sekaligus pemahaman mengenai tugas dan fungsi Majelis Kehormatan Notaris Wilayah.

Kata Kunci: Majelis Kehormatan; Notaris; Persetujuan; Minuta Akta 


\section{A. Pendahuluan}

Notaris selaku Pejabat Pembuat Akta yang eksistensinya diakui oleh negara mempunyai tanggung jawab, baik kepada masyarakat maupun di hadapan pengadilan, khususnya hal yang berkaitan dengan masalah Minuta Akta. ${ }^{1}$ Sebagai pejabat umum, notaris diberikan kewenangan untuk membuat akta otentik mengenai semua perbuatan, perjanjian dan penetapan yang didasarkan pada peraturan perundang-undangan yang berlaku.

Kehadiran Notaris dimaksudkan untuk membantu dan melayani masyarakat yang membutuhkan alat bukti tertulis yang bersifat otentik mengenai keadaan, peristiwa atau perbuatan hukum. Secara substantif Akta notaris dapat berupa suatu keadaan, peristiwa atau perbuatan hukum yang dikehendaki oleh para pihak agar dituangkan dalam bentuk akta autentik untuk dijadikan sebagai alat bukti dan berdasarkan pada peraturan perundang-undangan bahwa tindakan hukum tertentu wajib dibuat dalam bentuk akta autentik. ${ }^{2}$ Jabatan notaris merupakan jabatan kepercayaan, maka keluhuran serta martabat jabatan notaris harus dijaga, baik ketika dalam menjalankan tugas jabatan maupun perilaku kehidupan notaris sebagai manusia yang secara langsung maupun tidak langsung mempengaruhi keluhuran dan martabat jabatan notaris. ${ }^{3}$ Pasal 12 huruf c UndangUndang Nomor 2 Tahun 2014 Tentang Jabatan Notaris menegaskan bahwa notaris diberhentikan tidak hormat dari jabatannya oleh Menteri Hukum dan Hak Asasi Manusia atas usul Majelis Pengawas Pusat (MPP), karena melakukan perbuatan hukum yang merendahkan kehormatan dan martabat notaris. ${ }^{4}$ Notaris hanya boleh memberi keterangan atau pendapat yang dapat dibuktikan kebenarannya, wajib bersikap tulus ikhlas terhadap klien dan mempergunakan segala sumber keilmuannya. Selain itu notaris juga wajib merahasiakan segala sesuatu yang

\footnotetext{
${ }^{1}$ Supriadi, 2006, Etika dan Tanggung Jawab Profesi Hukum di Indonesia, Cetakan 1, Sinar Grafika, Jakarta, hal. 45

${ }^{2}$ Habib Adjie, 2009, Sanksi Perdata \& Administratif Terhadap Notaris Sebagai Pejabat Publik, Cetakan PT. Refika Aditama, Bandung, hal. 32.

${ }^{3}$ Anand, G., \& Hernoko, A. (2017). Upaya Tuntutan Hak Yang Dapat Dilakukan Oleh Pihak Yang Berkepentingan Terhadap Akta Notaris Yang Cacat Yuridis. Perspektif Hukum, 16(2), 154-174. doi: http://dx.doi.org/10.30649/phj.v16i2.62

${ }^{4}$ Habib Adjie, op.cit, Sanksi Perdata \& Administratif Terhadap Notaris, hal.60
} 
Jurnal Al-Adalah: Jurnal Hukum dan Politik Islam

Vol. 4, No. 1, Januari 2019: 52-81

P-ISSN: 2406-8802

E-mail: aladalah@iain-bone.ac.id

http://jurnal.iain-bone.ac.id/index.php/aladalah

diketahuinya mengenai masalah yang dihadapi klien, karena kepercayaan yang telah diberikan kepadanya.

Dalam UU Jabatan Notaris diatur bahwa ketika notaris dalam menjalankan tugas jabatannya terbukti melakukan pelanggaran, maka notaris dapat dikenai sanksi, berupa sanksi perdata, sanksi administrastif, dan kode etik jabatan Notaris. Dalam praktik, biasa ditemukan suatu kenyataan bahwa suatu pelanggaran hukum yang dilakukan oleh Notaris, yang sebenarnya hanya bisa dijatuhi sanksi administratif atau sanksi perdata bahkan hanya berupa sanksi kode etik jabatan Notaris. Akan tetapi dalam praktik banyak ditemukan jika ada akta notaris dipermasalahkan oleh para pihak atau pihak ketiga lainnya, maka sering pula notaris ditarik sebagai pihak yang turut serta melakukan atau membantu melakukan suatu tindak pidana, yaitu membuat atau memberikan keterangan palsu ke dalam akta notaris. ${ }^{5}$ Dalam hal ini notaris secara sengaja atau tidak sengaja bersama-sama dengan para pihak untuk membuat akta dengan maksud dan tujuan untuk menguntungkan pihak atau penghadap tertentu saja atau merugikan penghadap lain yang kemudian harus dibuktikan di Pengadilan.

Untuk itu diperlukan mekanisme perlindungan hukum untuk seorang notaris dalam hal proses pemeriksaan terkait tuduhan dugaan pemalsuan akta maupun dugaan-dugaan lain dalam ranah pidana. Mekanisme tersebut telah diatur dalam Pasal 66 UUJN melalui pemeriksaan permulaan oleh Majelis Kehormatan Notaris Wilayah (MKNW) sehingga seorang notaris yang dipanggil oleh penyidik harus memperoleh persetujuan dari MKNW untuk dipanggil dan diperiksa di hadapan penyidik. Namun kenyataannya masih ada notaris yang langsung dipanggil oleh penyidik dan diperiksa tanpa memperoleh persetujuan terlebih dahulu dari Majelis Kehormatan Notaris Wilayah. Perlindungan terhadap minuta akta yang dipegang oleh notaris juga turut menjadi perhatian sehingga dibutuhkan persetujuan dari Majelis Kehormatan Notaris Wilayah jika minuta akta dibutuhkan penyidik dalam pemeriksaan terhadap seorang notaris.

${ }^{5}$ Habib Adjie, Hukum Notariat Di Indoensia Tafsiran Tematik Terhadp UU NO. 30 Tahun 2004 tentang Jabatan Notaris, Rafika Aditama, Bandung, 2008, hal. 24. 
Jika dilihat dari permasalahan di atas maka dalam hal ini fungsi dari MKNW sangat krusial terkait dengan tugas dan fungsi notaris sebagai pejabat publik, terutama dalam hal jika ada permintaan dari penyidik, baik untuk memperoleh persetujuan pemanggilan terhadap diri notaris maupun persetujuan dalam permintaan fotokopi minuta akta guna proses penyidikan. Untuk itu dalam proses pemeriksaan pada MKNW diharapkan dapat diperoleh hasil pemeriksaan yang mencerminkan adanya perlindungan hukum yang sesuai untuk semua pihak. Hal ini dirasa perlu mengingat bahwa dalam UUJN tidak diatur secara jelas mengenai perlindungan hukum bagi notaris dalam kasus pidana dari akta yang telah dibuatnya, contohnya akta yang dibuat berdasarkan data dan informasi yang dipalsukan oleh para pihak.

\section{B. Pentingnya Persetujuan Majelis Kehormatan Notaris Wilayah untuk Kepentingan Pemeriksaan dalam Tindak Pidana yang dilakukan oleh Notaris}

Profesi notaris merupakan suatu pekerjaan dengan keahlian khusus yang menuntut pengetahuan luas, serta tanggung jawab yang berat untuk melayani kepentingan umum dan inti tugas notaris adalah mengatur secara tertulis dan autentik hubungan-hubungan hukum antara para pihak yang secara mufakat meminta jasa notaris. Notaris perlu memperhatikan apa yang disebut sebagai perilaku profesi yang memiliki unsur-unsur sebagai berikut : Akta notaris berisi keterangan dan pernyataan para pihak, dibuat di atas kehendak atau permintaan para pihak untuk selanjutnya notaris membuatnya dalam bentuk yang sudah ditentukan menurut undang-undang.

Notaris bukan pihak dalam akta tersebut, pencantuman nama notaris dalam akta karena perintah undang-undang. Membatalkan akta notaris berarti secara lahiriah tidak mengakui akta tersebut sehingga akta tersebut bukan akta notaris. Penilaian akta notaris secara lahiriah bukan akta notaris harus dibuktikan dari awal sampai akhir akta bahwa ada syarat yang tidak dipenuhi mengenai bentuk suatu akta notaris. Jika dapat dibuktikan bahwa akta notaris tersebut tidak memenuhi syarat sebagai sebuah akta notaris, maka akta tersebut akan 
Jurnal Al-Adalah: Jurnal Hukum dan Politik Islam

Vol. 4, No. 1, Januari 2019: 52-81

P-ISSN: 2406-8802

E-mail: aladalah@iain-bone.ac.id

http://jurnal.iain-bone.ac.id/index.php/aladalah

mempunyai nilai pembuktian sebagaimana akta di bawah tangan, yang penilaian pembuktiannya tergantung kepada pengakuan para pihak dan hakim. ${ }^{6}$ Secara pidana notaris dapat dituntut ke pengadilan apabila dikemudian hari aparat yang berwenang seperti kepolisian dan jaksa penuntut umum dapat membuktikan bahwa notaris secara sadar dan meyakinkan telah menguntungkan salah satu pihak dan merugikan pihak lainnya.

Akta autentik sebagai alat bukti yang sempurna, pembuktian dalam hukum acara mempunyai arti yuridis berarti hanya berlaku bagi pihak-pihak yang berperkara atau yang memperoleh hak dari mereka dan tujuan dari pembuktian adalah untuk memberi kepastian kepada Hakim tentang adanya suatu peristiwaperistiwa tertentu. Maka pembuktian harus dilakukan oleh para pihak dan siapa yang harus membuktikan atau yang disebut juga sebagai beban pembuktian berdasarkan Pasal $184 \mathrm{KUHAP}^{7}$ yaitu keterangan saksi, keterangan ahli, surat, petunjuk dan keterangan terdakwa.

Sebuah akta autentik merupakan dokumen yang sah dan dapat menjadi alat bukti yang sempurna, yang artinya dapat dianggap semua yang tertera dalam akta merupakan hal yang benar, kecuali ada akta lain yang dapat membuktikan isi akta pertama tersebut salah. Oleh karena itu pembuatan sebuah akta otentik menjadi sesuatu yang penting karena dengan memilikinya berarti kita memiliki bukti atau landasan yang kuat di mata hukum. Terdapat beberapa alasan yang menunjang kekuatan hukum sebuah akta autentik. Akta otentik dibuat di hadapan seorang pejabat umum negara sehingga legalitasnya dapat dipastikan, ditambah lagi bahwa seorang pejabat umum negara tidak memiliki keberpihakan dalam pembuatan akta. Hal ini berbeda dengan akta yang dibuat sendiri, meskipun disaksikan pihak ketiga, tetapi hal itu tidak dapat menjadi sebuah jaminan. Dapat saja pihak-pihak yang terlibat dalam pembuatan akta menyangkal keterlibatannya. Hal ini dapat saja terjadi karena mereka mempunyai kepentingan sendiri-sendiri.

\footnotetext{
${ }^{6}$ Liliana Tedjosaputro, Etika Profesi dan Profesi Hukum, Aneka Ilmu, Semarang, 2003 hal 75 .

${ }^{7}$ Kitab Undang-Undang (KUHPer, KUHP, \& KUHAP), Grahamedia Press, hal. 741
} 
Pelaksanaan tugas jabatan notaris yaitu dalam lingkup hukum pembuktian, hal ini karena tugas dan kewenangan notaris yaitu membuat alat bukti yang diinginkan oleh para pihak dalam hal tindakan hukum tertentu. Keberadaan alat bukti tersebut dalam ruang lingkup atau tataran hukum pidana. Oleh karena pekerjaan notaris membuat akta tersebut atas permintaan dari penghadap, maka tanpa adanya permintaan dari para penghadap notaris tidak akan membuat suatu apapun. Notaris membuat akata berdasarkan alat bukti atau keterangan/ pernyataan para pihak yang dinyatakan atau diterangkan atau diperlihatkan kepada atau di hadapan notaris untuk selanjutnya notaris membingkainya secara lahiriah, formil dan materiil didalam bentuk akta notaris dengan tetap berpijak pada aturan hukum atau tata cara dan prosedur pembuatan akta dan aturan hukum yang berkaitan dengan tindakan hukum yang bersangkutan untuk didituangkan dalam akta.

Peran notaris dalam hal ini juga untuk memberikan nasehat hukum yang sesuai dengan permasalahan yang ada sebagaimana yang diwajibkan oleh Pasal 15 ayat (2) huruf e UUJN. Apapun nasehat hukum yang diberikan kepada para pihak dan kemudian dituangkan ke dalam akta yang bersangkutan tetap sebagai keinginan atau keterangan para pihak yang bersangkutan, tidak dan bukan sebagai keterangan atau pernyataan notaris.

Dalam praktik notaris ditemukan kenyataan jika ada akta notaris dipermasalahkan oleh para pihak atau pihak lainnya, maka sering pula notaris ditarik sebagai pihak yang turut serta melakukan atau membantu melakukan suatu tindak pidana, yaitu membuat atau memberikan keterangan palsu ke dalam akta notaris. Hal ini pun menimbulkan kerancuan mungkinkah seorang notaris secara sengaja atau khilaf bersama-sama para penghadap/pihak untuk membuat akta yang diniatkan sejak awal untuk melakukan suatu tindak pidana. Dal hal ini tidak berarti notaris terhindar dari perbuatan melawan hukum atau tidak dapat dihukum atau kebal terhadap hukum. Notaris bisa saja dihukum pidana jika dapat dibuktikan di pengadilan bahwa secara sengaja atau tidak sengaja notaris bersama-sama dengan para pihak/ penghadap untuk membuat akta dengan 
Jurnal Al-Adalah: Jurnal Hukum dan Politik Islam

Vol. 4, No. 1, Januari 2019: 52-81

P-ISSN: 2406-8802

E-mail: aladalah@iain-bone.ac.id

http://jurnal.iain-bone.ac.id/index.php/aladalah

maksud dan tujuan untuk menguntungkan pihak atau penghadap tertentu saja atau merugikan penghadap yang lain. Jika hal ini terbuti dalam persidangan maka notaris tersebut wajib dihukum. Oleh Karena itu, hanya notaris yang tidak amanah dalam menjalankan tugas jabatannya ketika membuat akta untuk kepentingan pihak tertentu dengan maksud untuk merugikan pihak tertentu atau untuk melakukan suatu tindakan yang melanggar hukum. ${ }^{8}$

Adapun faktor yang menyebabkan notaris diperlukan kehadirannya dalam pemeriksaan perkara pidana, yakni apabila akta yang dibuat oleh notaris menimbulkan kerugian yang diderita para pihak dan pihak maupun pihak lain dan berdasarkan bukti bahwa notaris patut diduga turut serta melakukan atau membantu melakukan suatu tindak pidana, berkaitan dengan kewenangan notaris berdasarkan Pasal 15 Undang-Undang Jabatan Notaris yaitu membuat akta autentik dengan adanya unsur-unsur tindak pidana. Berdasarkan hasil wawancara dan penelitian yang telah dilakukan penulis di sekretariat Majelis Kehormatan Wilayah, diperoleh data dari surat-surat permohonan dari penegak hukum yakni penyidik dan kejaksaan. Adapun surat-surat permohonan yang diteliti ini merupakan surat yang diterima dan dicatat oleh sekretaris MKN Wilayah dalam rentang waktu dari Tahun 2016 sampai dengan tahun 2018. Pada Tahun 2016 sejak anggota MKN Wilayah dilantik secara serentak di Kota Surabaya pada bulan September 2016, telah diterima 7 (tujuh) permohonan dari Penyidik yang masuk sejak bulan Oktober 2016. Selanjutnya pada Tahun 2017, sekretaris MKN Wilayah menerima 33 (tiga puluh tiga) surat permohonan dari penyidik dan kejaksaan. Sedangkan hingga bulan Mei 2018 telah diterima 21 (dua puluh satu) permohonan dari penyidik untuk memeriksa notaris, sehingga secara keseluruhan terdapat 61 (enam puluh satu) surat permohonan dari penegak hukum yang telah diterima oleh MKN Wilayah Provinsi Sulawesi Selatan. ${ }^{9}$

Setelah meneliti surat-surat permohonan yang masuk di MKN Wilayah, dapat diambil sampel mengenai beberapa unsur-unsur tindak pidana yang menjadi

\footnotetext{
${ }^{8}$ Habib Adjie, Op.Cit, hal. 24.

9 Wawancara dengan Mohammad Yani, Sekretaris Majelis Kehormatan Notaris Wilayah Provinsi Sulawesi Selatan, Makassar 18 Juli 2018
} 
dugaan terjadinya tindak pidana khususnya terkait dalam pembuatan akta notaris, antara lain:

1. Pasal 55 KUHP yaitu turut serta melakukan tindak pidana.

Berdasarkan penelitian penulis terhadap salah satu permohonan dari penyidik Ditreskrimum Polda Sulawesi Selatan tertanggal 15 November 2016, bahwa sedang dilakukan penyidikan dugaan tindak pidana turut serta melakukan perbuatan pidana terkait obyek tanah di Kabupaten Gowa dengan dasar Sertifikat Hak Milik. Adapun dalam kasus ini dimintakan keterangan dari 2 (dua) orang notaris yang pernah mengeluarkan akta pengikatan jual beli dan kuasa menjual sehingga diperlukan keterangannya sebagai saksi. Dalam menindaklanjuti permohonan dari Ditreskrimum tersebut, MKN Wilayah telah melakukan rapat/ sidang yang keputusannya tidak memberikan izin terhadap pemanggilan/ pemeriksaan notaris dimaksud. Adapun pertimbangan dari MKN Wilayah adalah bahwa dalam hal ini notaris telah membuat surat kuasa sudah sesuai dengan prosedur dan ketentuan perundang-undangan. Selanjutnya bahwa surat kuasa menjual tersebut merupakan akta autentik sehingga akta tesebut telah membuktikan sendiri keabsahannya sesuai dengan peraturan perundangundangan.

2. Pasal 263 KUHP yaitu pemalsuan surat.

Berdasarkan penelitian yang penulis lakukan dari surat dari penyidik Ditreksrimum Polda Sulawesi Selatan tertanggal 26 Februari 2018 bahwa sedang dilakukan penyelidikan dugaan tindak pidana membuat surat palsu dan menggunakan surat palsu dengan cara pelapor melakukan kerja sama pengelolaan bimbingan belajar milik terlapor yang dituangkan dalam perjanjian kerja sama yang dibuat di notaris yang pada saat itu dijabat oleh notaris pengganti karena yang bersangkutan sedang cuti. Pada perjanjian kerja sama tersebut, notaris pengganti diduga merubah bunyi Pasal 8 dari denda sebesar Rp. 10.000.000,- (sepuluh juta rupiah) menjadi Rp. 10.000.000.000,- (sepuluh milyar rupiah). Hal ini tentunya menimbulkan 
Jurnal Al-Adalah: Jurnal Hukum dan Politik Islam

Vol. 4, No. 1, Januari 2019: 52-81

P-ISSN: 2406-8802

E-mail: aladalah@iain-bone.ac.id

http://jurnal.iain-bone.ac.id/index.php/aladalah

kerugian yang sangat besar kepada pihak pelapor yang juga klien notaris. Dalam menindakllanjuti surat permohonan dari penyidik, MKN Wilayah telah mengundang terlapor dalam hal ini notaris yang bersangkutan namun pada hari rapat yang telah ditentukan terlapor tidak hadir untuk mengikuti rapat pemeriksaan dengan MKN Wilayah. Selanjutnya diketahui bahwa notaris telah langsung memenuhi panggilan penyidik untuk memberikan keterangannya dan telah dicatat dalam berita acara penyidikan.

3. Pasal 266 KUHP yaitu memberikan keterangan palsu dalam akta autentik. Berdasarkan penelitian dari data yang diperoleh dari sekretaris MKN Wilayah, surat perintah penyidikan reskrim Polda Sulawesi Selatan tertanggal 24 Mei 2017 disampaikan bahwa terjadi dugaan tindak pidana menempatkan keterangan palsu ke dalam akta autentik sebagaimana dilaporkan oleh masyarakat yang menjelaskan bahwa notaris telah membuat Risalah Rapat Pembina sebuah yayasan yang isinya mengenai perubahan pengurus dalam yayasan tersebut. Oleh karena tidak dilampirkannya laporan polisi maka penulis tidak dapat mengetahui kronologis peristiwa terhadap kasus ini. Namun dengan dugaan menempatkan keterangan palsu ke dalam akta autentik dikaitkan dengan pembuatan akta perubahan yayasan maka dapat diduga bahwa terbitnya akta tersebut tidak atas sepengetahuan pendiri/ pengurus yayasan.

4. Pasal 372 KUHP yaitu penggelapan.

Yaitu barang siapa dengan sengaja memiliki dengan melawan hak sesuatu barang yang sama sekali atau sebagian termasuk kepunyaan orang lain dan barang itu ada di tangannya bukan karena kejahatan, karena penggelapan. Dalam hal ini notaris dalam menjalankan jabatannya telah menerima honorarium atas jasa hukum berdasarkan kewenangannya dari para pihak tetapi notaris tidak menerbitkan akta yang dibuatnya dalam waktu yang cukup lama, karena telah menggunakan honorarium itu untuk kepentingan pribadi atau kepentingan lain, sehingga para pihak yang menggunakan jasa 
hukumnya dirugikan. Terdapat banyak permohonan pemeriksaan notaris yang diduga melakukan tindak pidana penggelapan, salah satunya dalam surat permohonan penyidik tertanggal 14 Januari 2018. Surat permohonan dari Satuan Reskrim Polres Pelabuhan Makassar sementara melakukan penyelidikan terhadap dugaan terjadinya tindak pidana penggelapan dana pengurusan biaya pajak, akta jual beli dan balik nama Sertifikat Hak Milik pelapor sehingga pengurusan menjadi terhambat dan tentunya menyebabkan kerugian kepada pihak pengguna jasa notaris. Terhadap permohonan tersebut, MKN Wilayah tidak memberikan persetujuan terhadap permohonan penyidik dengan alasan bukan merupakan kewenangan MKN Wilayah dalam hal yang berkaitan dengan pelaksanaan tugas PPAT.

5. Pasal 378 KUHP yaitu penipuan

Dalam hal ini penyidik Polrestabes Makassar melalui suratnya tertanggal 18 Mei 2017 sedang menangani laporan dugaan tindak pidana penipuan yang dilakukan oleh notaris dimana pelapor merasa pernah membuat akta peralihan hak namun hingga pelapor menyampaikan laporannya, akta dimaksud belum pernah selesai atau belum pernah diperlihatkan kepada pelapor. Menanggapi permohonan pemeriksaan notaris dimaksud, MKN Wilayah telah melaksanakan sidang dan memanggil notaris bersangkutan yang mana telah diputuskan bahwa MKN Wilayah memberikan persetujuan pemeriksaan terhadap notaris tersebut.

6. Pasal 385 KUHP yaitu menjual, menukarkan atau membebani dengan credit verband (Hak Tanggungan) atas tanah yang belum bersertifikat.

Berdasarkan data yang diperoleh dari sekretaris MKN Wilayah, melalui surat perintah penyidikan dari Ditreskrimum Polda Sulsel yang kemudian mengirimkan surat permohonan persetujuan tertanggal 15 November 2016 terhadap notaris yang diduga melakukan tindak pidana yang melanggar Pasal 385 KUHP. Adapun informasi mengenai perbuatan melawan hukum 
Jurnal Al-Adalah: Jurnal Hukum dan Politik Islam

Vol. 4, No. 1, Januari 2019: 52-81

P-ISSN: 2406-8802

E-mail: aladalah@iain-bone.ac.id

http://jurnal.iain-bone.ac.id/index.php/aladalah

seperti apa yang dilakukan terlapor atas tanah yang menjadi obyek yang diperkarakan sesuai dengan rumusan Pasal 385 KUH Pidana, yakni menjual, menukarkan atau membebani dengan hak tanggungan belum didapatkan oleh penulis karena tidak dilampirkannya kronologis perkara dalam surat permohonan penyidik. Namun sudah jelas bahwa di atas obyek tanah tersebut mempunyai hak milik orang lain yang dapat dibuktikan oleh pelapor melalui dasar Sertifikat Hak Milik dari orang tua pelapor. Hal ini yang kemudian mendasari pelapor untuk memasukkan laporan kepada pihak kepolisian untuk dilakukan penyidikan dan menghadirkan saksi yakni notaris yang terlibat dalam pembuatan akta agar dokumen-dokumen yang terkait dengan obyek tanah tersebut baik surat kuasa menjual maupun akta pengikatan jual beli dapat dimintakan fotokopinya dari notaris.

Untuk mendapatkan keterangan dari notaris baik secara formil maupun materiil berkaitan dengan akta yang dibuatnya berdasarkan laporan para pihak atau pihak lain yang dirugikan atas akta tersebut (aktanya berindikasi adanya tindak pidana). perlu dilakukan pemeriksaan yang obyektif oleh penyidik, karena Kepolisian wajib menerima laporan pengaduan masyarakat dan menindak lanjuti dengan pemanggilan guna diminta keterangannya karena fungsi penyidik Kepolisian adalah membuat terang suatu tindak pidana. Terhadap kehadiran notaris dalam pemeriksaan perkara pidana khususnya penyidikan di Kepolisian, Undang-undang Jabatan Notaris dan kode etik notaris tidak mengatur terkait tanggung jawab notaris secara pidana terhadap akta yang dibuatnya manakala terbukti melakukan pelanggaran terhadap hukum pidana.

Sejak berlakunya Permenkumham Nomor 7 Tahun 2016 atas amanah Pasal 66 UUJN, pelaksanaan tugas dan fungsi Majelis Kehormatan Notaris khususnya Majelis Kehormatan Notaris Wilayah telah berjalan sesuai dengan koridor yang semestinya. Namun tidak bisa dipungkiri bahwa masih ada beberapa kendala dalam pelaksanaannya baik dari aspek aturan hukum maupun dari teknis 
pelaksanaan di lapangan. Kehadiran MKN ini diharapkan dapat memberikan suatu bentuk perlindungan hukum yang optimal bagi Notaris serta dapat memberikan pembinaan secara preventif maupun kuratif dalam penegakan UUJN dalam menjalankan tugas jabatannya sebagai pejabat umum. ${ }^{10}$

Anggota Majelis Kehormatan Notaris tidak hanya dituntut untuk mengerti mengenai hal ikhwal yang berkenaan dengan pelaksanaan tugas jabatan notaris, melainkan harus memahami pula tentang hukum acara, di samping integritasnya tidak diragukan. Oleh karena itu anggota Majelis Kehormatan Notaris harus menyadari bahwa Majelis Kehormatan Notaris bukan sebagai pembela bagi para Notaris, melainkan sebagai institusi yang mempunyai tugas dan fungsi untuk mendudukkan secara proporsional dan professional tentang perlu tidaknya fotokopi minuta akta dan/atau surat-surat yang dilekatkan pada minuta akta atau protokol notaris dalam penyimpanan notaris maupun keterangan notaris sebagaimana diminta oleh penyidik, penuntut umum, atau hakim untuk keperluan proses peradilan.

Majelis Kehormatan Notaris sebagaimana dimaksud dalam Pasal 66 ayat (1) dan Pasal 66A UUJN, telah dibentuk dan mempunyai tugas dan fungsi sebagaimana tercantum dalam Permenkumham Nomor 7 Tahun 2016, namun sampai saat ini belum ditetapkan pedoman bagi Majelis Kehormatan Notaris dalam melaksanakan tugas dan fungsi tersebut. Dengan pedoman tersebut diharapkan Majelis Kehormatan Notaris dalam melaksanakan tugas dan fungsinya menjadi lebih efektif. Tujuan penyusunan pedoman pelaksanaan tugas dan fungsi Majelis Kehormatan Notaris adalah untuk memberikan arahan dan tuntunan bagi anggota Majelis Kehormatan Notaris dalam menjalankan jabatannya, sehingga profesionalisme dan kualitas kerjanya menjadi lebih meningkat. Dalam rancangan pedoman tersebut dicantumkan mengenai syarat-syarat dan tata cara pengambilan fotokopi minuta akta dan/ atau surat-surat yang dilekatkan pada minuta akta atau protokol notaris dalam penyimpanan notaris dan pemanggilan notaris, notaris pengganti, pejabat sementara notaris, dan werda notaris.

10 Dahlan, Kewenngan Majelis Kehormatan Notaris Terkait Aspek Pidana di Bidang Kenotariatan, Kanun Jurnal Ilmu Hukum, Vol. 18, No. 1, April 2016 
Jurnal Al-Adalah: Jurnal Hukum dan Politik Islam

Vol. 4, No. 1, Januari 2019: 52-81

P-ISSN: 2406-8802

E-mail: aladalah@iain-bone.ac.id

http://jurnal.iain-bone.ac.id/index.php/aladalah

Permasalahan dari aspek aturan hukum yang dihadapi adalah mengenai kewenangan MKN Wilayah sebagaimana diatur dalam Pasal 1 Permenkumham Nomor 7 Tahun 2016 tentang Majelis Kehormatan Notaris yakni dalam hal pemeriksaan dan memberikan persetujuan atau penolakan untuk kepentingan penyidikan dan proses peradilan yang hanya terbatas kepada notaris, notaris pengganti dan pejabat sementara saja. Lalu bagaimana dengan notaris yang pensiun/werda ${ }^{11}$ (karena telah sesuai batas umur atau mengundurkan diri atau diberhentikan) dan juga mantan notaris pengganti dan pejabat sementara notaris. Jika mereka masih hidup dan suatu saat ada permintaan dari penyidik, penuntut umum atau hakim dipanggil untuk keperluan yang berkaitan dengan aktanya ketika yang bersangkutan masih menjalankan tugas jabatan sebagai notaris, apakah harus ada izin dari MKN Wilayah, ataukah MKN Wilayah hanya berlaku untuk notaris, notaris pengganti dan pejabat sementara notaris yang masih aktif. Permenkumham tersebut tidak mengatur untuk hal seperti itu.

Apa yang tertuang dalam awal dan akhir akta yang menjadi tanggung jawab notaris adalah ungkapan yang mencerminkan keadaan yang sebenarbenarnya pada saat pembuatan akta. ${ }^{12} \mathrm{Hal}$ ini dinyatakan secara tegas dalam Pasal 65 UUJN bahwa notaris, notaris pengganti dan pejabat sementara notaris bertanggung jawab atas setiap akta yang dibuatnya meskipun protokol notaris telah diserahkan atau dipindahkan kepada pihak penyimpan protokol notaris. Hal ini tentunya menguatkan alasan mengapa notaris pengganti dan pejabat sementara notaris wajib memenuhi panggilan penegak hukum yang sebelumnya harus melalui mekanisme pemeriksaan di MKN Wilayah. Sehubungan dengan hal tersebut, Pasal 65 UUJN menilai bahwa ${ }^{13}$ mereka yang diangkat sebagai notaris, notaris pengganti dan pejabat sementara notaris dianggap menjalankan tugas pribadi dan seumur hidup sehingga tanpa ada batas waktu pertanggungjawaban selanjutnya bahwa pertanggungjawaban notaris, notaris pengganti dan pejabat

\footnotetext{
12 Tan Thong Kie, Studi Notariat-Serba Serbi Praktek Notaris, Jakarta, Ichtiar Baru Van Hoeve, 2000, hal. 166

${ }^{13}$ Habib Adjie, Meneropong Khasanah Notaris dan PPAT Indonesia, Bandung, PT. Citra Aditya Bakti, 2009, hal. 43
} 
sementara notaris dianggap melekat, kemanapun dan dimanapun mantan notaris, mantan notaris pengganti dan mantan pejabat notaris sementara berada.

Memperhatikan ketentuan Pasal 65 UUJN tersebut bahwa notaris bertanggung jawab atas setiap akta yang dibuatnya meskipun protokol notaris telah diserahkan atau dipindahkan kepada pihak penyimpan protokol notaris. Akibat hukum dari akta notaris tersebut tetap melekat sepanjang akta notaris tersebut tidak diubah atau dibatalkan oleh para pihak yang mengikatkan diri di dalam akta notaris tersebut. Artinya walaupun notaris yang membuat akta tersebut telah berakhir masa jabatannya, akta notaris yang dibuat tetap berlaku sebagai undang-undang bagi mereka yang membuatnya. Sedangkan bagi notaris hanya bertanggung jawab terhadap formil akta yang dibuatnya, bukan terhadap isi dari akta tersebut. Oleh karenanya notaris dalam membuat akta harus memenuhi standar prosedur, sehingga pertanggung jawwaban notaris terhadap akta yang dibuatnya harus melekat seumur hidup pada diri notaris.

Majelis Kehormatan Notaris Wilayah Provinsi Sulawesi Selatan dalam pelaksanaan tugas dan fungsinya pernah beberapa kali menerima permohonan pemeriksaan terhadap pemegang protokol notaris, namun MKN Wilayah tidak dapat memberikan izin terhadap pemanggilan guna pemeriksaan notaris dalam hal ini jika notaris sebagai pemegang protokol maka ia tidak bertanggung jawab terhadap akta yang dibuat oleh notaris sebelumnya. Seorang notaris yang telah ditunjuk secara sah untuk menyimpan protokol notaris tidak dapat menerangkan ataupun memberikan kesaksian mengenai akta yang dimohonkan karena akta tersebut tidak dibuat dihadapan notaris pemegang protokol yang bersangkutan. MN Wilayah juga pernah menerima panggilan terhadap mantan notaris pengganti, namun akibat tidak diaturnya ketentuan mengenai bagaimana seharusnya mantan notaris pengganti dalam hal dipanggil oleh penyidik kaitannya dengan keharusan adanya persetujuan terlebih dahulu dari MKN Wilayah.

Permasalahan lain dalam pelaksanaan tugas dan fungsi yang dihadapi oleh MKN Wilayah adalah mengenai tidak disertakannya resume/ ringkasan pokok perkara dari penegak hukum baik dari penyidik maupun dari penuntut umum. Hal ini sering menjadi penghambat dari majelis dalam acara pemeriksaan notaris jika 
Jurnal Al-Adalah: Jurnal Hukum dan Politik Islam

Vol. 4, No. 1, Januari 2019: 52-81

P-ISSN: 2406-8802

E-mail: aladalah@iain-bone.ac.id

http://jurnal.iain-bone.ac.id/index.php/aladalah

berdasarkan dari surat permohonan saja. Seringkali dalam beberapa surat permohonan yang diterima oleh sekretaris MKN Wilayah tidak cukup menjelaskan mengenai kronologis perkara sehingga seringkali majelis sulit melakukan identifikasi mengenai hubungan hukum antara pelapor dengan terlapor. Tidak lengkapnya informasi dalam surat permohonan dari penegak hukum inipun menimbulkan kesulitan anggota MKN Wilayah dalam pengambilan keputusan. Ketidakjelasan juga sering ditemukan dalam surat permohonan dalam hal status hukum notaris dalam hal dipanggil oleh penyidik, apakah sebagai pribadi atau sebagai masyarakat umum dimana hal tersebut sangat penting untuk dijadikan sebagai dasar oleh MKN WIlayah untuk pengambilan keputusan.

Selain itu pihak penegak hukum juga seringkali keliru dalam menilai laporan dari masyarakat, dimana perlu dipahami pula bahwa MKN Wilayah hanya melakukan pemeriksaan terhadap notaris dalam melaksanakan tugas dan fungsinya sebagai notaris, bukan dalam hal sebagai PPAT. Untuk itu penegak hukum wajib mengetahui dan mengidentifikasi dalam hal apa dugaan tindak pidana tersebut dilakukan, apakah sebagai pejabat notaris atau sebagai pejabat pembuat akta tanah. Hal ini penting mengingat Majelis Kehormatan Notaris Wilayah tidak berwenang menangani pengawasan jabatan PPAT melainkan merupakan kewenangan dari Kantor Wilayah Badan Pertanahan. Perlu diketahui bahwa PPAT merupakan pejabat umum yang diberikan kewenangan untuk membuat akta-akta autentik mengenai perbuatan hukum tertentu mengenai hak atas tanah seperti membuat Akta Jual Beli (AJB) atau Hak Milik Atas Satuan Rumah Susun.

Dalam hal MKN Wilayah mengeluarkan keputusan persetujuan dan penolakan juga tidak terlepas dari berbagai polemik. Hal ini terjadi karena keputusan yang dikeluarkan oleh majelis menimbulkan berbagai reaksi baik dari notaris itu sendiri maupun dari penyidik, penuntut umum maupun dari hakim. Reaksi yang muncul dari para penegak hukum terhadap putusan yang tidak memberikan persetujuan, MKN Wilayah dianggap hanya melindungi notaris, menghambat proses peradilan yang singkat dan murah serta notaris akan dianggap kebal hukum. 
Hal ini juga disampaikan Kepala Bidang Hukum Polda Sulawesi Selatan dalam kesempatan Rapat Persiapan Koordinasi Dilkumjalkpol di Kanwil Kementerian Hukum dan HAM Suawesi Selatan, bahwa dalam berbagai kesempatan rapat ataupun sosialisasi yang diselenggarakan dengan melibatkan notaris, dapat ditangkap bahwa notaris seringkali salah menilai bahwa sebagai notaris mereka memiliki kekebalan hukum. Notaris dalam bertindak berdasarkan tugas jabatannya memang memiliki hak dan kewajiban khusus jika dihadapkan dengan masalah hukum. Hal ini dikarenakan tugas jabatan notaris yang mengharuskan seorang notaris merahasiakan segala sesuatu yang ada kaitannya dengan tugas jabatannya. Namun jika seorang notaris bertindak dalam kapasitasnya sebagai warga negara maka ia tidak dapat dikecualikan dalam hukum dan harus bertanggung jawab atas tindakannya jika melanggar hukum.

Reaksi yang timbul dari notaris terhadap putusan memberikan persetujuan adalah, MKN Wilayah dianggap tidak melindungi notaris. Notaris juga menganggap putusan MKN Wilayah tersebut merupakan penjatuhan sanksi atau hukuman bagi notaris. Melalui putusan tersebut notaris menganggap dan mengakui bahwa notaris memang telah melakukan kesalahan/ kelalaian dalam melaksanakan tugas. Padahal menurut Anggota MKN Wilayah, Ria Trisnomurti bahwa putusan MKN Wilayah dalam memberikan persetujuan adalah dengan maksud membuat terang suatu peristiwa yang terjadi apakah perbuatan tersebut merupakan tindak pidana atau tidak. Untuk itu notaris diberikan persetujuan untuk pemeriksaannya agar notaris dapat memberikan sendiri keterangannya kepada pihak penyidik. $^{14}$

Dalam hal reaksi dari notaris tersebut dapat ditegaskan bahwa MKN Wilayah tidak memiliki kewenangan untuk menjatuhkan sanksi hukuman, ataupun menyatakan notaris bersalah atau tidak. MKN Wilayah juga tidak memiliki kewenangan untuk menyatakan apakah akta notaris tidak mengikat, cacat hukum, batal atau dapat dibatalkan dan lain sebagainya. Tugas MKN Wilayah hanya memberikan atau tidak memberikan persetujuan berdasarkan

14 Wawancara dengan Ria Trisnomurti, Anggota Majelis Kehormatan Notris Wilayah, Makassar 29 Juni 2018. 
Jurnal Al-Adalah: Jurnal Hukum dan Politik Islam

Vol. 4, No. 1, Januari 2019: 52-81

P-ISSN: 2406-8802

E-mail: aladalah@iain-bone.ac.id

http://jurnal.iain-bone.ac.id/index.php/aladalah

keterangan yang diberikan secara langsung oleh notaris dalam acara pemeriksaan di MKN Wilayah. Namun masih ada saja anggapan dari pihak notaris bahwa putusan MKN Wilayah dalam memberikan persetujuan akan dijadikan alasan untuk meningkatkan status notaris yang tadinya hanya sebagai saksi namun akhirnya menjadi tersangka. Permasalahan lain yang terjadi di lapangan adalah masih adanya beberapa orang notaris yang langsung menghadap kepada penyidik tanpa terlebih dahulu datang memenuhi panggilan untuk mengikuti pemeriksaan di MKN Wilayah. Hal ini tentunya sangat disayangkan baik dari pihak notaris maupun dari pihak penegak hukum. Jika dilihat dari sisi penyidik, penuntut umum atau hakim maka hal ini menandakan bahwa dalam hal ini para penegak hukum masih kurang memahami regulasi berkaitan dengan tugas dan fungsi MKN Wilayah. Seperti dalam salah satu contoh permohonan penyidik terhadap salah seorang notaris di Kota Makassar yang diterima oleh Sekretaris MKN Wilayah tidak hadir pada sidang/ pertemuan dengan MKN Wilayah pada waktu yang telah ditetapkan. Oleh sekretaris MKN Wilayah, notaris yang bersangkutan kemudian dihubungi via telepon dan diketahui bahwa notaris yang bersangkutan telah datang memenuhi panggilan dari penyidik untuk memberikan keterangannya dan telah dibuatkan berita acara pemeriksaannya.

Tindakan yang dilakukan notaris tersebut tentu saja membawa akibat yakni melanggar kerahasiaan jabatan notaris dan akan menimbulkan masalah lain, yang semula masalah mungkin saja terjadi hanya di antara para pihak saja akhirnya mejadi masalah antara notaris dan para pihak atau salah satu pihak. Lebih lanjut mengenai hambatan MKN Wilayah dalam melaksankan tugasnya yakni tidak lepasnya bantuan dan dukungan aktif dari Sekretaris dan staf sekretariat MKN Wilayah yang belum secara tegas diatur dalam Permenkumham Nomor 7 Tahun 2016. Adapun tugas dimaksud antara lain berupa dibutuhkannya verifikasi administrasi telebih dahulu oleh sekretaris mengenai permohonan penyidik, penuntut umum atau hakim dan juga membuat berita acara pemeriksaan Majelis Pemeriksa. Berdasarkan hasil wawancara penulis dengan Sekretaris MKN Wilayah Provinsi Sulawesi Selatan bahwa saat ini sekretaris dengan dibantu oleh staf sekretariat masih sebatas membantu tugas MKN Wilayah dalam proses 
pemeriksaan dengan diawali doleh menyiapkan surat panggilan terhadap notaris terkait permohonan penyidik, penuntut umum atau hakim dan selanjutnya menyiapkan dan menyampaikan surat jawaban MKN Wilayah kepada penyidik, penunutut umum atau hakim.

Profesi hukum dituntut untuk memiliki rasa kepekaan atas nilai keadilan dan kebenaran serta mewujudkan kepastian hukum bagi pencapaian dan oemeliharaan ketertiban masyarakat. Selain itu profesi hukum berkewajiban selalu mengusahakan dengan penuh kesadaran yang bermoral untuk mengetahui segala aturan hukum yang dapat dipertanggung jawabkan. Secara ilmiah bagi tegaknya hukum dan keadilan dan terutama diperuntukkan bagi mereka yang membutuhkannya. Sebagai seorang yang memiliki profesi, anggota Majelis Kehormatan Notaris Wilayah diharapkan memiliki pengetahuan atau kecakapan yang hanya diketahui dan dipahami oleh mereka sesuai dengan bidang keahlian masing-masing yang tentu saja tidak dimiliki oleh masyarakat pada umumnya. Pertanggungjawaban notaris sebagai pejabat umum terhadap akta yang telah dibuatnya dan di tandatangani oleh para pihak tersebut memperoleh suatu kekuatan pembuktian, dimana isi akta yang dibuat notaris merupakan kehendak para pihak untuk dituangkan dalam akta tersebut sehingga notaris hanya sebagai penengah dan memberi masukan hukum kepada para pihak tentang kehendak yang dimasukan kedalam akta tersebut. ${ }^{15}$ Apabila akta notaris tersangkut masalah pidana notaris hanya dipanggil sebagai saksi, dan mengharuskan notaris hadir dalam pemeriksaan awal yaitu penyidikan ditingkat kepolisian, penuntutan di Kejaksaan sampai dengan proses persidangan. Mengingat bahwa akta otentik tersebut yang dibuat oleh notaris akan dipergunakan sebagai alat bukti apabila terjadi persengketaan di pengadilan.

Dalam hal Majelis Kehormatan Notaris Wilayah mengeluarkan sebuah keputusan baik persetujuan maupun penolakan terhadap permohonan pemeriksaan adanya dugaan tindak pidana yang dilakukan oleh notaris akan berimplikasi baik

15 Ahmad Reza Andhika, Pertanggungjawaban Notaris dalam Perkara Pidana Berkaitan dengan Akta yng Dibuatnya Menurut Undang-Undang Nomor 2 Tahun 2014 Tentang Perubahan tas Undang-Undang Nomr 30 Tahun 2004, Premise Law Jurnal, Vol 1, 2016 
Jurnal Al-Adalah: Jurnal Hukum dan Politik Islam

Vol. 4, No. 1, Januari 2019: 52-81

P-ISSN: 2406-8802

E-mail: aladalah@iain-bone.ac.id

http://jurnal.iain-bone.ac.id/index.php/aladalah

kepada notaris maupun kepada pihak yang berkepentingan. Majelis Kehormatan Notaris (MKN) merupakan lembaga yang diamanatkan Undang-undang jabatan notaris untuk memberikan persetujuan atau izin kepada penegak hukum untuk memeriksa notaris ketika notaris diduga atau disangka melakukan pelanggaran hukum. kehadiran MKN Wilayah dapat membantu penyidik dalam menentukan ada tidaknya unsur pidana terkait dengan minuta akta dan protokol notaris.

Tanggung jawab yang diamanahkan kepada MKN Wilayah menjadi berat karena dengan diberikannya penolakan atas permintaan penegak hukum, maka berarti MKN Wilayah memberikan keyakinan penuh bahwa notaris yang bersangkutan tidak bertanggung jawab atas dugaan telah terjadi tindak pidana dari pihak yang berkepentingan/ pihak yang melaporkan notaris tersebut. sedangkan jika MKN Wilayah mengeluarkan keputusan persetujuan atas permintaan pemeriksaan notaris maka notaris secara tidak langsung melimpahkan tanggung jawab kepada notaris untuk bertanggung jawab penuh terhadap pihak yang berkepentingan.

\section{Mekanisme Pemeriksaan dan Pemanggilan Notaris untuk Kepentingan Pemeriksaan Dugaan Tindak Pidana Notaris yang Dilakukan Notaris}

Setiap subjek hukum jika diduga melakukan suatu tindakan pidana sebagaimana yang diatur dalam Kitab Undang-Undang Hukum Pidana mkaa boleh dilakukan suatu proses penyidikan untuk membuktikan subjek hukum tersebut bersalah atau tidak. Tetapi pada beberapa profesi seperti notaris yang juga termasuk ke dalam subyek hukum mempunyai keistimewaan untuk menolak proses penyidikan yang dilakukan jika belum memperoleh persetujuan dari MKN Wilayah. Hal ini sering menimbulkan rasa ketidakadilan dari masyarakat dikarenakan keistimewaan yang dimiliki oleh notaris tersebut. seakan-akan notaris mempunyai tameng tersendiri untuk lolos dari jeratan hukum pidana.

Pemanggilan notaris sebagai saksi tidak dapat dilakukan begitu saja. Menurut ketentuan Pasal 66 UUJN pemanggilan notaris harus mendapatkan persetujuan Majelis Kehormatan Notaris Wilayah. Perlunya persetujuan Majelis Kehormatan Notaris Wilayah ini mengingat notaris sebagai pejabat umum yang 
harus merahasiakan akta yang dibuatnya. Sebagai jabatan kepercayaan notaris wajib merahasiakan isi akta dan segala keterangan yang diperoleh dalam pelaksanaan jabatannya. Hal ini sejalan sengan sumpah jabatan yang diucapkan sebelum notaris melaksanakan jabatannya, sebagaimana ditegaskan dalam Pasal 4 Ayat 2 UUJN. Notaris tidak bisa secara bebas mengungkapkan atau membocorkan rahasia jabatannya kepada siapapun kecuali terdapat peraturan perundang-undangan lain yang memperbolehkannya untuk membuka rahasia jabatannya, sumpah jabatan tersebut ditegaskan sebagai salah satu kewajiban notaris yang diatur dalam Pasal 16 Ayat (1) huruf f UUJN yang menyatakan dalam menjalankan jabatannya, notaris berkewajiban merahasiakan segala sesuatu mengenai akta yang dibuatnya dan segala keterangan yang diperoleh guna pembuatan akta sesuai dengan sumpah/ janji jabatan, kecuali undang-undang menentukan lain.

Dalam hal pemeriksaan perkara pidana yang diduga dilakukan oleh notaris, penyidik, penuntut umum ataupun hakim harus meminta persetujuan dari Majelis Kehormatan Notaris Wilayah dengan mengajukan permohonan tertulis dalam Bahasa Indonesia kepada Majelis Kehormatan Notaris Wilayah sesuai dengan wilayah kerja Notaris yang bersangkutan, yang tembusannya disampaikan kepada Notaris. Dalam Pasal 24 Permenkumham Nomor 7 Tahun 2016 diatur bahwa dalam melakukan pemeriksaan, majelis berwenang melakukan pemanggilan terhadap notaris berdasarkan adanya permohonan dari penyidik, penuntut umum atau hakim. Untuk itu notaris wajib hadir membawa minuta akta/ surat yang dilekatkan pada minuta akta serta buku daftar aktanya, dan/ atau suratsurat lainnya yang berkaitan dengan akta yang menjadi pokok perkara dan dalam proses pemeriksaan untuk diperlihatkan kepada MKN Wilayah.

Majelis Pemeriksa berwenang memeriksa dan memberikan persetujuan atau penolakan atau permohonan tidak dapat diterima atau permohonan dikembalikan terhadap permintaan penyidik, penuntut umum atau hakim terkait pengambilan fotokopi minuta akta dan surat-surat yang dilekatkan pada minuta akta dan/atau protokol notaris dalam penyimpanan notaris dan pemanggilan 
Jurnal Al-Adalah: Jurnal Hukum dan Politik Islam

Vol. 4, No. 1, Januari 2019: 52-81

P-ISSN: 2406-8802

E-mail: aladalah@iain-bone.ac.id

http://jurnal.iain-bone.ac.id/index.php/aladalah

notaris. Majelis Pemeriksa memberikan persetujuan atau penolakan atau permohonan tidak dapat diterima atau permohonan dikembalikan setelah mendengar keterangan langsung dari notaris bersangkutan. Permohonan penyidikan juga bisa ditolak oleh Majelis Kehormatan Notaris dengan memberikan alasan yang jelas mengenai penolakannya kepada penegak hukum. Tidak dijelaskan di dalam UUJN batasan mengenai penerimaan dan penolakan yang bisa dilakukan oleh MKN ilayah, sehingga dapat dimungkinkan jika ada dugaan tindak pidana yang ddilakukan oleh notaris maka MKN sendiri yang melakukan pembinaan terhadap notaris yang nakal dengan tujuan menjaga nama baik organisasi notaris.

Sebagai tambahan berdasarkan hasil wawancara penulis dengan salah satu anggota MKN Wilayah Provinsi Sulawesi Selatan dari unsur notaris, yakni Ria Trisnomurti bahwa penting bagi penyidik, penuntut umum dan hakim untuk memberikan kejelasan dalam surat permohonannya mengenai kedudukan notaris apakah sebagai saksi, tersangka atau lainnya. Kemudian untuk permintaan fotokopi minuta/ surat yang dilekatkan, harus dengan alasan yang jelas, begitu juga dengan permintaan tanda tangan/ cap jempol yang tertera di minuta akta/ surat yang dilekatkan harus diuji di Laboratorium Forensik dengan alasan yang jelas. $^{16}$

Dalam melaksanakan jabatannya tidak dapat dipungkiri bahwa notaris juga memiliki kemungkinan melakukan suatu pelanggaran hukum baik yang disengaja maupun tidak disengaja. Sepanjang notaris melaksanakan tugas dan jabatannya sesuai dengan amanat UJN dan telah memenuhi tata cara dalam pembuatan suatu akta autentik maka notaris tersebut tidak akan mendapatkan tuntutan atau gugatan atas suatu pelanggaran hukum. Tetapi bisa saja disaat notaris sudah melaksanakan tugas dan jabatannya sesuai dengan peraturan yang berlaku tetapi para pihak yang mempunyai itikad buruk dan melakukan perbuatan melanggar hukum. Untuk itu notaris dituntut untuk benar-benar teliti dan hati-hati saat membuat akta autentik dngan menanyakan data diri para pihak sesuai dengan identitas asinya. Prosedur

\footnotetext{
16 Wawancara dengan Ria Trisnomurti, Anggota Majelis Kehormatan Notris Wilayah, Makassar 29 Juni 2018.
} 
ini bertujuan agar pembuatan akta autentik tersebut berdasarkan suatu itikad baik. Untuk membuktikan apakah seorang notaris terlibat atau tidak dalam suatu tindak pidana maka harus dilakukan proses penyidikan oleh pihak yang berwenang. Menurut Pasal 66 ayat (1) UUJN, pemanggilan notaris untuk proses penyidikan yang diduga melakukan tindak pidana harus mendapatkan persetujuan terlebih dahulu dari Majelis Kehormatan Notaris. Prosedur untuk memperoleh persetujuan dari Majelis Kehormatan Notaris adalah penyidik harus memberikan surat permohonan kepada MKN Wilayah untuk melakukan proses penyidikan kepada notaris yang diduga melakukan tindak pidana.

Dalam UUJN sendiri tidak mengatur seperti apa sanksi yang harus diberikan jika seorang notaris bertindak atas jabatannya melakukan suatu pelanggaran hukum. Dirasa sangat tidak adil apabila sanksi yang diberikan adalah sanksi yang diatur dalam UUJN sedangkan pelanggaran tindak pidana yang dilakukan termasuk kedalam unsur tindak pidana dalam Kitab Undang-Undang Hukum Pidana.

Mekanisme penanganan permohonan persetujuan pemeriksaan notaris atau pengambilan fotokopi minuta akta oleh penyidik, penuntut umum ataupun hakim untuk kepentingan proses peradilan adalah hanya merupakan kewenangan MKN Wilayah yang tidak bertingkat atau berjenjang dan bersifat final, tidak ada upaya banding. Sedangkan MKN Pusat hanya mempunyai tugas dan fungsi memberikan pembinaan-pembinaan kepada MKN Wilayah dalam pelaksanaan tugas dan fungsinya atas persetujuan MKN Pusat. Berdasarkan ketentuan dalam Pasal 23 Permenkumham No. 7 Tahun 2016 memuat bahwa permohonan persetujuan pengambilan minuta akta atau protokol notaris dan pemanggilan notaris yang diajukan oleh pihak Penyidik, Penuntut Umum ataupun Hakim untuk hadir dalam pemeriksaan yang terkait dengan akta atau protokol notaris yang berada dalam penyimpanan notaris diajukan kepada Ketua MKN Wilayah sesuai dengan wilayah kerja notaris yang bersangkutan. Permohonan tersebut disampaikan secara tertulis dalam Bahasa Indonesia dan tembusannya disampaikan kepada notaris yang bersangkutan. Permohonan tersebut harus memuat paling sedikit 
Jurnal Al-Adalah: Jurnal Hukum dan Politik Islam

Vol. 4, No. 1, Januari 2019: 52-81

P-ISSN: 2406-8802

E-mail: aladalah@iain-bone.ac.id

http://jurnal.iain-bone.ac.id/index.php/aladalah

nama notaris, alamat kantor notaris, nomor akta dan/atau surat yang dilekatkan pada minuta akta atau protokol notaris dalam penyimpanan notaris dan pokok perkara yang disangkakan.

Surat diserahkan dan diterima oleh MKN Wilayah melalui sekretariat dan diberi tanda dan tanggal penerimaan. Ketua MKN Wilayah wajib memberikan jawaban berupa persetujuan atau penolakan terhadap surat permohonan tersebut dalam jangka waktu paling lama 30 hari kerja terhitung sejak tanggal diterimanya permohonan, dan apabila jangka waktu 30 hari tersebut terlampaui, maka MKN Wilayah dianggap menerima permintaan persetujuan. Berdasarkan permohonan tersebut paling lambat 5 hari setelah surat diterima diadakan rapat MKN Wilayah untuk menentukan terhadap permohonan itu harus ditindaklanjuti atau tidak. Apabila hasil putusan rapat menganggap tidak perlu ditindaklanjuti, maka MKN Wilayah harus memberitahukan kepada penyidik, penuntut umum atau hakim yang menyampaikan permohonan tersebut berikut dengan alasannya.

Tata kerja dalam Majelis Kehormatan Notaris Wilayah secara sistematis diatur dalam Peraturan Menteri Hukum dan HAM Nomor 7 Tahun 2016 tentang Majelis Kehormatan Notaris. Dalam Pasal 21 telah disebutkan bahawa dalam melakukan pemeriksaan terhadap notaris, ketua Majelis Kehormatan Notaris Wilayah membentuk majelis pemeriksa dalam waktu paling lambat 5 (lima) hari kerja terhitung sejak tanggal laporan diterima. Tim pemeriksa beranggotakan sebanyak 3 (tiga) orang yang terdiri dari setiap unsur anggota Majelis Kehormatan Notaris Wilayah. Majelis pemeriksa terdiri atas 1 (satu) orang ketua merangkap anggota dan 2 (dua) orang anggota dan dibantu oleh 1 (satu) orang sekretaris.

Pelaksanaan rapat Majelis Kehormatan Notaris Wilayah sedapat-dapatnya dihadiri oleh seluruh anggota Majelis Kehormatan Notaris Wilayah. Apabila setelah diusahakan dengan sungguh-sungguh tidak dapat dihadiri oleh seluruh anggota Majelis Kehormatan Notaris Wilayah, maka rapat Majelis Kehormatan Notaris Wilayah dinyatakan sah apabila dihadiri oleh sekurang-kurangnya 2/3 (dua per tiga) dari jumlah anggota Majelis Kehormatan Notaris Wilayah. Namun apabila pada saat melakukan pemeriksaan terhadap notaris sesuai dengan jadwal 
yang telah ditentukan ternyata terdapat anggota Majelis Pemeriksa yang tidak hadir (berhalangan), Ketua Majelis Kehormatan Notaris Wilayah berwenang menunjuk penggantinya, tanpa memperhatikan unsur keanggotaan Majelis Kehormatan Notaris Wilayah. Dalam hal keadaan mendesak pemanggilan dapat dilakukan melalui faksminili dan/atau surat elektronik yang segera disusul dengan surat pemanggilan paling waktu paling lambat 5 (lima) hari kerja sebelum pemeriksaan dilakukan. Notaris wajib hadir memenuhi panggilan Majelis Pemeriksa dan tidak boleh diwakilkan, serta tidak boleh didampingi pengacara. Namun dalam hal notaris tidak hadir setelah dipanggil secara sah dan patut sebanyak 2 (dua) kali berturut-turut, Majelis Pemeriksa dapat mengambil keputusan terhadap permintaan penyidik, penuntut umum atau hakim.

Notaris wajib hadir memenuhi panggilan Majelis Pemeriksa dan tidak boleh diwakili ataupun melalui kuasa. Apabila notaris yang bersangkutan setelah 2 kali berturut-turut telah dilakukan pemanggilan secara sah dan patut oleh ketua MKN Wilayah/ Ketua Majelis Pemeriksa, tidak juga hadir, maka majelis pemeriksa tetap melakukan pemeriksaan tanpa kehadiran dari notaris yang bersangkutan. Majelis Pemeriksa akan memeriksa notaris pada hari, waktu dan tempat yang telah ditentukan. Sidang pemeriksaan dibuka oleh Ketua Majelis Pemeriksa dengan dilanjutkan oleh pencocokan data identitas notaris, melalui Surat Keputusan Pengangkatan Notaris, Berita Acara Sumpah, Kartu Anggota dan mencocokkan serta melihat catatan-catatan notaris yang bersangkutan dalam Buku Rapor Notaris dan Buku Daftar Anggota INI yang salinannya disampaikan oleh Pengda INI. Ketua sidang menanyakan kondisi kesehatan, jiwa dan raga notaris. Ketua sidang kemudian menyampaikan pokok perkara dan maksud pemeriksaan yyang dilakukan terhadap notaris tersebut. Ketua sidang juga menanyakan kesediaan notaris untuk diperiksa. Selanjutnya notaris membuat dan menandatangani surat pernyataan yang berkaitan dengan tanggung jawab atas kebenaran keterangan-keterangan yang diberikan dalam sidang dimaksud. Pencocokan akta/ surat/ buku-buku daftar akta yang menjadi pokok perkara juga dilakukan dalam sidang pemeriksaan oleh MKN Wilayah. Sidang dimaksud harus dilakusanakan guna membuat terang permasalahan, melalui pemeriksaan dan 
Jurnal Al-Adalah: Jurnal Hukum dan Politik Islam

Vol. 4, No. 1, Januari 2019: 52-81

P-ISSN: 2406-8802

E-mail: aladalah@iain-bone.ac.id

http://jurnal.iain-bone.ac.id/index.php/aladalah

pembinaan-pembinaan terhadap notaris yang bersangkutan, yang nantinya hasil pemeriksaan dan pembinaan-pembinaan tersebut digunakan sebagai pertimbangan Majelis Pemeriksa untuk memberikan persetujuan atau tidak memberikan persetujuan permohonan dimaksud.

Mejelis Pemeriksa memberikan persetujuan atau penolakan setelah mendengar keterangan langsung dari notaris yang bersangkutan yang mana keterangan terebut dituangkan dalam Berita Acara Pemeriksaan. Setiap hasil pemeriksaan Majelis Pemeriksa dilaporkan kepada Ketua MKN Wilayah untuk dicatat ke dalam buku rapor notaris yang bersangkutan dan menyampaikan hail putusan kepada pemohon dan Pengda INI untuk dicatat dalam buku daftar notaris dan tembusannya disampaikan kepada notaris yang bersangkutan, Dewan Kehormatan Notaris, Majelis Pengawas Notaris, dan Majelis Kehormatan Notaris Pusat.

Syarat pemanggilan tersebut merupakan batas kewenangan MKN Wilayah yang telah ditentukan secara limitatif (terbatas) yang ada kaitannya dengan pelaksanaan tugas jabatan sebagai notaris. Jika ada notaris yang melakukan suatu tindakan pidana yang tidak ada kaitannya dengan pelaksanaan tugas jabatannya, misalnya menerima titipan uang pembayaran pajak dari para penghadap yang kemudian tidak dibayarkan ke instansi yang berwenang, maka hal seperti itu bukan kualifikasi untuk memerlukan izin dari MKN Wilayah. Namun dalam praktik notaris, terdapat tindakan notaris yang sering dilaporkan oleh para penghadap sebagai bentuk pengingkaran dari penghadap sendiri, seperti tidak pernah penghadap tersebut menghadap pada jam/pukul yang disebutkan pada awal akta; tidak pernah menghadap pada hari atau tanggal yang disebutkan pada awal akta; notaris tidak membacakan/ menjelaskan akta di hadapan penghadap; nama saksi akta tidak pernah hadir ketika pembacaan akta dilakukan; para penghadap tidak datang bersamaan.

Fakta yang sering terjadi ketika para penghadap bersengketa karena yang diperjanjikan dalam akta merugikan salah satu penghadap atau ada dari tindakan penghadap yang merugikan penghadap lainnya sehingga salah satu penghadap 
mengajukan gugatan pembatalan akta. Sengketa yang terjadi antara para pihak ini sering menjadi laporan ke pihak kepolisian yang akhirnya menjadi penyebab notaris dilibatkan. Padahal dalam membuat suatu akta autentik, notaris hanya menuangkan kehendak para pihak yang telah bersepakat.

Keputusan Rapat Majelis Kehormatan Notaris Wilayah diambil secara musyawarah untuk mufakat. Dalam hal musyawarah setelah diusahakan dengan sungguh-sungguh tidak dapat dicapai mufakat, keputusan diambil dengan suara terbanyak. Setiap hasil pemeriksaan majelis pemeriksa dilaporkan kepada Ketua Majelis Kehormatan Notaris Wilayah.

Dalam hal diberikannya persetujuan oleh Majelis Kehormatan Notaris Wilayah, maka akan dikeluarkan Surat Keputusan dan Berita Acara Pemeriksaan yang ditandatangani oleh Tim Pemeriksa, Surat Keputusan beserta lampirannya akan dikirimkan kepada instansi yang mengirim permohonan baik dari penyidik, penuntut umum maupun dari hakim. Penyitaan surat atau tulisan lain dari mereka yang berkewajiban menurut undang-undang untuk merahasiakannya, sepanjang tidak menyangkut rahasia negara, hanya dapat dilakukan atas persetujuan mereka atau atas izin khusus ketua pengadilan negeri setempat kecuali undang-undang menentukan lain. Notaris merupakan pejabat yang menyimpan minuta akta dan dalam menjalankan tugasnya berkewajiban untuk merahasiakan segala sesuatu mengenai akta yang dibuatnya dan segala keterangan yang diperoleh guna pembuatan akta sesuai dengan sumpah/ janji jabatan. Oleh karena itu pada dasarnya penyitaan minuta akta notaris pada dasarnya harus dilakukan dengan persetujuan Majelis Kehormatan Notaris Wilayah sesuai dengan wilayah kerja Notaris yang bersangkutan.

Untuk kepentingan penyidikan, penuntutan ataupun proses peradilan harus dengan persetujuan Majelis Kehormatan Notaris Wilayah sehingga para penegak hukum yang meminta persetujuan harus menunggu surat keputusan yang menyatakan tentang persetujuan dalam hal pemeriksaan notaris untuk meminta keterangan dan pengambilan fotokopi minuta akta. Penyitaan terhadap surat atau tulisan lain dapat dilakukan atas perintah penyidik kepada pemegang atau yang 
Jurnal Al-Adalah: Jurnal Hukum dan Politik Islam

Vol. 4, No. 1, Januari 2019: 52-81

P-ISSN: 2406-8802

E-mail: aladalah@iain-bone.ac.id

http://jurnal.iain-bone.ac.id/index.php/aladalah

menguasai untuk menyerahkan kepada penyidik. Dalam Pasal 43 KUHAP dinyatakan bahwa surat atau tulisan yang disimpan atau dikuasai oleh orang tertentu, dimana oranag tertentu yang menyimpan atau menguasai surat itu, diwajibkan merahasiakannya oleh undang-undang. Misalnya, seorang notaris adalah pejabat atau orang tertentu yang menyimpan dan menguasai akta tertamen, dan oleh undang-undang diwajibkan untuk merahasiakan isinya.

Jika mereka yang berkewajiban menurut undang-undang untuk merahasiakan surat atau tulisan itu "setuju atas penyitaan" yang dilakukan penyidik, penyitaan dapat dilakuan menurut undang-undang untuk merahasiakan "tidak setuju atas penyitaan yang akan dilakukan penyidik, dalam hal seperti ini penyitaan hanya dapat dilakukan atas izin khusus Ketua Pengadilan Negeri setempat. Namun penyitaan dalam hal ini tidak terlepas kaitannya dengan kewajiban notaris menyimpan minuta dimaksud, sehingga wujud penyitaan yang dibenarkan terbatas pada kebolehan penyidik untuk menyalin atau memfotokopinya. ${ }^{17}$

Majelis Kehormatan Notaris Wilayah dalam mengeluarkan keputusan memberikan persetujuan untuk memberikan fotokopi minuta akta sesuai permintaan penyidik, penuntut umum ataupun hakim, maka notaris wajib memenuhi keputusan tersebut. Sesuai dengan Pasal 25 ayat (3) Permenkumham Nomor 7 Tahun 2016. Berdasarkan hasil wawancara dengan anggota MKN Wilayah Provinsi Sulawesi Selatan, Ria Trisnomurti yang berasal dari unsur notaris, diperoleh penjelasan bahwa minuta akta untuk kepentingan penyidikan tidak dapat serta merta disita karena minuta akta merupakan arsip negara yang tidak boleh diambil tanpa prosedur. Akta Notaris dan Protokol Notaris bukan hanya menjaga kepastian, ketertiban, dan perlindungan hukum bagi pihak yang berpentingan semata-mata, melainkan sekaligus juga bagi masyarakat secara keseluruhan. ${ }^{18}$ Adapun tata cara pengambilan minuta akta masih mengacu pada Peraturan Menteri Hukum dan Hak Asasi Manusia Republik Indonesia Nomor :

\footnotetext{
${ }^{17}$ Yahya Harahap, Op.Cit, hal. 274

18 Muriel Cattleya Maramis, Tata Cara Pemanggilan Notaris untuk Kepentingan Proses Peradilan Pidana Berkaitan dengan Akta yang Dibuatnya, Lex Crimen Vol.I/No.1/Jan-Mrt/2012
} 
M.03.10 Tahun 2007 Tentang Pengambilan Minuta Akta dan Pemanggilan Notaris. Namun peraturan ini masih merupakan peraturan lama yang masih belum menyesuaikan perubahan kewenangan pemberian persetujuan dari Majelis Pengawas Daerah Notaris menjadi Majelis Kehormatan Notaris Wilayah.

Hal ini tentu saja menjadi celah dari segi peraturan hukum yang berlaku dan harus sesegera mungkin untuk ditindaklanjuti dengan perubahan Peraturan Menteri Hukum dan Hak Asasi Manusia karena sudah tidak sesuai dengan perubahan yang terjadi saat ini. Berdasarkan penjelasan yang diperoleh dari Wakil Ketua MKN Wilayah Provinsi Sulawesi Selatan ini dapat diketahui mengenai beberapa hal yang harus diperhatikan notaris berkaitan dengan tata cara penyerahan fotokopi minuta akta atau surat untuk pembuktian dalam penyidikan dan penuntutan, yaitu notaris meminta surat persetujuan dari MKN Wilayah dari pemohon; notaris meminta surat permohonan dari pemohon; notaris meminta dari pemohon surat penunjukan sebagai pelaksanaan tugas resmi dari Kepolisian dan Kejaksaan; minuta akta/ surat yang diminta difotokopi oleh notaris; pemohon dan notaris bersama-sama mencocokkan minuta akta dengan fotokopinya dengan disaksikan oleh 2 (dua) orang saksi.

\section{Penutup}

Pentingnya persetujuan Majelis Kehormatan Notaris Wilayah (MKNW) dalam pemeriksaan dan pengambilan fotokopi minuta akta terkait dugaan tindak pidana yang dilakukan Notaris sangat berkaitan erat dengan fungsi MKN Wilayah dalam memberikan perlindungan kepada notaris terkait dengan kewajiban notaris untuk merahasiakan isi akta sebagaimana tercantum dalam Pasal 18 ayat (2) huruf b Permenkumham Nomor 7 Tahun 2016 tentang Majelis Kehormatan Notaris. MKN Wilayah melakukan pemeriksaan dengan mendengar keterangan langsung dari notaris yang bersangkutan untuk kemudian dapat memberikan keputusan berupa persetujuan ataupun penolakan terhadap pemeriksaan seorang notaris di tahap penyidikan, penuntutan ataupun peradilan. Proses ini diharapkan efektifitas pelaksanaannya guna menjamin perlindungan hukum tidak hanya kepada notaris terkait dengan kewajiban notaris untuk merahasiakan isi akta tapi juga secara 
Jurnal Al-Adalah: Jurnal Hukum dan Politik Islam

Vol. 4, No. 1, Januari 2019: 52-81

P-ISSN: 2406-8802

E-mail: aladalah@iain-bone.ac.id

http://jurnal.iain-bone.ac.id/index.php/aladalah

tidak langsung untuk memberikan perlindungan terhadap masyarakat pengguna jasa notaris.

\section{Daftar Pustaka}

Adjie, Habib , 2008, Hukum Notaris Indonesia Tafsir Tematik Tehadap UU No. 2 Tahun 2014 Tentang Jabatan Notaris. Bandung, Rwfika Aditama. , 2009, Meneropong Khasanah Notaris dan PPAT Indonesia, Bandung, PT. Citra Aditya Bakti. 2009, Sanksi Perdata \& Administratif Terhadap Notaris Sebagai Pejabat Publik, Bandung, PT. Refika Aditama.

Liliana Tedjosaputro, 2003, Etika Profesi dan Profesi Hukum, Semarang, Aneka Ilmu.

Kie, Tan Thong Kie, 2000, Studi Notariat-Serba Serbi Praktek Notaris, Jakarta, Ichtiar Baru Van Hoeve.

Widiatmoko, 2007, Himpunan Peraturan Jabatan Notaris, Jakarta, Pradnya Paramita.

Prodjodikoro, Wirjono, 1992, Hukum Acara Pidana di Indonesia, Bandung, Sumur.

Harahap,Yahya 2014, Pembahasan Permasalahan dan Penerapan KUHAP, Sinar Grafika, Cetakan 15.

Maramis, Muriel Cattleya , Tata Cara Pemanggilan Notaris untuk Kepentingan Proses Peradilan Pidana Berkaitan dengan Akta yang Dibuatnya, Lex Crimen Vol.I/No.1/Jan-Mrt/2012

Ahmad Reza Andhika, Pertanggungjawaban Notaris dalam Perkara Pidana Berkaitan dengan Akta yng Dibuatnya Menurut Undang-Undang Nomor 2 Tahun 2014 Tentang Perubahan tas Undang-Undang Nomr 30 Tahun 2004, Premise Law Jurnal, Vol 1, 2016.

Anand, G., \& Hernoko, A. (2017). Upaya Tuntutan Hak Yang Dapat Dilakukan Oleh Pihak Yang Berkepentingan Terhadap Akta Notaris Yang Cacat Yuridis. Perspektif Hukum, 16(2), 154-174. doi: http://dx.doi.org/10.30649/phj.v16i2.62

Dahlan, Kewenangan Majelis Kehormatan Notaris Terkait Aspek Pidana di Bidang Kenotariatan, Kanun Jurnal Ilmu Hukum, Vol.18, No. 1, April 2016.

Kitab Undang-Undang Hukum Pidana

Kitab Undang-Undang Hukum Acara Pidana 
Undang-Undang No. 2 Tahun 2014 Tentang Perubahan Atas Undang-Undang No.30 Tahun 2004 Tentang Jabatan Notaris (Lembaran Negara Republik Indonesia Tahun 2014 Nomor 3, Tambahan Lembaran Negara Republik Indonesia Nomor 5491)

Peraturan Menteri Hukum dan Hak Asasi Manusia Nomor 7 Tahun 2016 Tentang Majelis Kehormatan Notaris

Peraturan Menteri Hukum dan Hak Asasi Manusia Republik Indonesia Nomor : M.03.10 Tahun 2007 Tentang Pengambilan Minuta Akta dan Pemanggilan Notaris 